\title{
EFFECT OF ALTERNATE-LONG FURROWS IRRIGATION ON CALCAREOUS SOILS PRODUCTIVITY
}

\author{
Hiekal $^{1}$, H. A. M.; S. A. AFiah'2; and F. M. Al-Borahy ${ }^{3}$
}

\section{ABSTRACT}

Field experiment was conducted along two successive seasons of winter (2004/2005) and summer (2005) at Maryout Experimental Station of the Desert Research Center, to evaluate the performance of alternate-long furrow irrigation system, using three irrigation water inflow rates on faba bean and sunflower crops productivity grown in calcareous soil. The experiments carried out in a split plot design with four replicates at random procedure. Irrigation system treatments were used as the main plots (120 m length with longitudinal soil surface slope 0.25\%) namely: every long-furrow irrigation (EFI), and alternate long-furrow irrigation (AFI). Three different water inflow rates designated as $Q_{1}, Q_{2}$, and $Q_{3}$ represented the sub plots: 105, 90, and $65 \mathrm{lpm} /$ furrow, respectively. The irrigation performance was evaluated through application efficiency $(A E \%)$ and distribution uniformity $(D U)$ parameters. Irrigation water use efficiency (IWUE) was estimated, which is related to water management by different treatments.

The obtained results indicated that application of AFI led to high significant interrelations between the values of seed yield and increases in $A E \%$ and DU values compared with EFI treatments. The highest mean DU values in $1^{\text {st. }}$ and $2^{\text {nd. }}$ seasons were 0.85 and 0.83 obtained by $Q_{2}$ and $Q_{1}$ treatments, respectively. Both faba and sunflower seed yield had significant increases with increasing the inflow rates under both studied irrigation systems. The highest yield mean value, with faba bean season, was $1046.5 \mathrm{~kg} / \mathrm{fed}$., while with sunflower season; it was $659.95 \mathrm{~kg} / \mathrm{fed}$. obtained by $\left(A F I+Q_{1}\right)$ treatment. The highest IWUE mean value, with faba bean season, was $0.83 \mathrm{~kg} / \mathrm{m}^{3}$, while with sunflower season; it was 0.27 $\mathrm{kg} / \mathrm{m}^{3}$. obtained by $\left(A F I+Q_{3}\right)$ treatment.

1- Soil Cons. Dept., Desert Research Center, Egypt

2- Plant Genetic Resources Dept., Desert Research Center, Egypt

3- Soil Phys. \& Chem. Dept., Desert Research Center, Egypt 
The two combined treatments $\left(A F I+Q_{1}\right)$ and $\left(A F I+Q_{2}\right)$ were the best treatments for soil moisture distribution uniformity, improving calcareous soil productivity and percent of sunflower oil content $(O \mathrm{C} \%)$ in seeds under the conditions of the present investigation.

Keywords: alternate long-furrow irrigation, soil moisture distribution uniformity, calcareous soil productivity, faba bean and sunflower.

\section{INTRODUCTION}

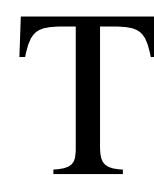

Today, as never before, irrigators face intense competition from other sectors of human economic activity for limited resources of water and energy. Irrigation system designers must address the difficult task of finding the "best" among many feasible design scenarios, rather than just seeking satisfactory ones. One of the important criteria in determining best management practices for irrigated agriculture that understand the interaction between irrigation system performance and the movement of water and solutes through the soil. Furrow irrigation practices can minimize water application, irrigation costs and chemical leaching and result in higher crop yields. Efficient irrigation is obtained by almost filling the crop root zone each irrigation, applying water uniformly and either minimizing or utilizing runoff. The uniformity of the water infiltrated along the furrow is related to soil conditions, field topography and the management practices (Benham et al., 1997). Many ways of conserving agricultural water have been investigated by Researchers (Hodges et al., 1989; and Graterol et al., 1993) have used wide spaced furrow irrigation or skipped crop rows as a means to improve water use efficiency (WUE). They fixed some furrows for irrigation, while adjacent furrows were not irrigated for the whole season. In general, these techniques are a trade off: a lower yield for a higher WUE. Water was saved mainly by reduced evaporation from the soil surface, as in the case of drip irrigation. Kang et al. (2000 b) showed that alternative drying of part of the root system was better than the drying of fixed part of the root zone in addition the alternate furrow irrigation drying led to an even distribution of the root system in the soil with better utilized of nutrients in the whole root zone. The results of more recent investigation (Mintesinot et al., 2004) showed that by using 
alternate furrows resulted highest water productivity values which the increase over the traditional management was $58 \%$. Clemmens et al. (1999) reported that over the past decade, there has been a gradual shift in Egypt towards development of farm mechanization systems. Efficient use of equipment requires tilling basins and furrows in long strips. However, for irrigation, these strips are typically broken up into small basins; this requires considerable labor and results in non-uniform and inefficient irrigation. The efficiency of surface (furrow) irrigation is a function of the field design, infiltration characteristics of the soil, and irrigation management practices such as application rate and time (Walker, 1989 and Hanson et al., 1993). Rice et al. (2001) they recommended to implementing a tail water recovery system and improving irrigation scheduling would potentially increase irrigation efficiency and reduce the over-irrigation and nitrate leaching observed for the commercial cotton production system. Oyonarte and Mateos (2002) illustrated that the spatial variability of the soil hydraulic characteristics is one of the variables determining irrigation performance. Relative seed yield of some sunflower hybrids was unaffected by soil salinity up to $4.8 \mathrm{dS} / \mathrm{m}$. Each unit increases in salinity above $4.8 \mathrm{dS} / \mathrm{m}$ reduced yield by $5 \%$. Yield reduction was attributed primarily to a reduction in seeds number per head. Oil concentration in the seed was relatively unaffected by increased soil salinity up to $10.2 \mathrm{dS} / \mathrm{m}$ (Francois, 1996).

Weiss (2000) indicated that sunflower seed constituents are normally a cultivar characteristic; oil content ranges between 25 and $48 \%$ but can reach $65 \%$, with a basic difference between seed produced under hot or temperate conditions. Growth and production of sunflower in the Nile River valley of Egypt is compromised by lack of natural rainfall or the use of salt-contaminated water for irrigation (Liu and Baird, 2003). Roy et al. (2006) mentioned that sunflower is an important oilseed crop containing 40-50 percent oil in the seeds. Potential seed yields can reach 5 tones/ha but average yields are much lower.

In this study, The aim was to evaluate the performance of alternate-long furrow irrigation system using some irrigation water inflow rates on calcareous soil productivity of faba bean and sunflower crops. 


\section{MATERIALS AND METHODS}

A field experiment was conducted along two successive seasons of winter (2004/2005) and summer (2005) at Maryout Experimental Station of Desert Research Center ( $\left.31^{\circ} 00^{\prime} 16^{\prime \prime} \mathrm{N}-29^{\circ} 47^{\prime} 08^{\prime \prime} \mathrm{E}\right)$, Alexandria Governorate, Egypt. For estimation the performance of alternate-long furrow irrigation system on the productivity of calcareous soil under three inflow rates of irrigation water. Representative soil samples were collected for determination some physical properties according to the methods described by Klute (1986) and some chemical properties determined according to the methods described by Black (1983). The soil was deep, well-drained calcareous sandy clay loam in texture and average values of some physical properties are represents in Table (1a) and chemical properties, Table (1b) of the soil experimental site throughout $1.0 \mathrm{~m}$ depth. Some properties of farmyard manure compost (FYM) represent in Table (1c), before $1^{\text {st. }}$ and $2^{\text {nd. }}$ seasons. Average values of some chemical properties of irrigation water throughout each season represents in Table (1d).

Table 1a: Some physical properties of the experimental soil site.

\begin{tabular}{|c|c|c|c|c|c|c|c|c|c|}
\hline \multicolumn{3}{|c|}{ Particle size distribution $(\%)$} & \multirow{2}{*}{$\begin{array}{c}* \mathrm{~K}_{\mathrm{sat}} \\
(\mathrm{cm} / \mathrm{h})\end{array}$} & $\begin{array}{c}\mathrm{D}_{\mathrm{p}} \\
\left(\mathrm{g} / \mathrm{cm}^{3}\right)\end{array}$ & $\begin{array}{c}\mathrm{D}_{\mathrm{b}} \\
\left(\mathrm{g} / \mathrm{cm}^{3}\right)\end{array}$ & $\begin{array}{c}\text { F.C. } \\
(\mathrm{v} \%)\end{array}$ & $\begin{array}{c}\text { W.P } \\
(\mathrm{v} \%)\end{array}$ & $\begin{array}{c}\text { A. W } \\
(\mathrm{v} \%)\end{array}$ \\
\hline $\begin{array}{c}\text { Coarse } \\
\text { Sand }\end{array}$ & $\begin{array}{c}\text { Fine } \\
\text { Sand }\end{array}$ & Silt & Clay & & & & & & \\
\hline \hline 22.48 & 32.34 & 22.53 & 22.65 & 2.32 & 2.34 & 1.51 & 20.47 & 8.3 & 12.17 \\
\hline
\end{tabular}

$* \mathrm{~K}_{\text {sat. }}=$ Saturated hydraulic Conductivity, $\mathrm{D}_{\mathrm{p}}=$ Particle density; $\mathrm{D}_{\mathrm{b}}=$ Bulk density; $\mathrm{FC}=$ Field capacity; $\mathrm{WP}=$ wilting point; and $\mathrm{A} . \mathrm{W}=$ Available water.

Table 1b: Some chemical properties of the experimental soil site.

\begin{tabular}{|c|c|c|c|c|c|c|c|c|c|c|c|}
\hline \multirow{2}{*}{$\begin{array}{c}\mathrm{CaCO}_{3} \\
(\%)\end{array}$} & \multirow[t]{2}{*}{$\mathrm{pH}$} & \multirow{2}{*}{$\begin{array}{l}\mathrm{OM} \\
(\%)\end{array}$} & \multirow{2}{*}{$\begin{array}{c}\mathrm{EC} \\
(\mathrm{dS} / \mathrm{m})\end{array}$} & \multicolumn{4}{|c|}{ Soluble Cations (meq/l) } & \multicolumn{4}{|c|}{ Soluble Anions (meq/l) } \\
\hline & & & & $\mathrm{Ca}^{++}$ & $\mathrm{Mg}^{++}$ & $\mathrm{Na}^{+}$ & $\mathrm{K}^{+}$ & $\mathrm{CO}_{3}=$ & $\mathrm{HCO}_{2}^{-}$ & $\mathrm{Cl}^{-}$ & $\mathrm{SO}_{4}=$ \\
\hline 28.02 & 7.41 & 0.84 & 2.71 & 7.65 & 2.67 & 15.91 & 0.88 & - & 2.12 & 17.41 & 7.58 \\
\hline
\end{tabular}

Table 1c: Some chemical properties of the applied FYM compost.

\begin{tabular}{|c|c|c|c|c|c|c|c|c|c|c|c|}
\hline Season & $\begin{array}{c}\text { OM } \\
(\%)\end{array}$ & $\mathrm{pH}$ & $\begin{array}{c}\mathrm{EC} \\
(\mathrm{dS} / \mathrm{m})\end{array}$ & $\begin{array}{c}\text { Total } \\
\mathrm{C} \\
(\%)\end{array}$ & $\begin{array}{c}\text { Total } \\
\mathrm{N}\end{array}$ & $\begin{array}{c}\mathrm{C} / \mathrm{N} \\
\text { ratio }\end{array}$ & $\begin{array}{c}\text { Total } \\
\mathrm{P} \\
(\%)\end{array}$ & $\begin{array}{c}\text { Total } \\
\mathrm{K}\end{array}$ & $\begin{array}{c}\text { Total } \\
\mathrm{Fe}\end{array}$ & $\begin{array}{c}\text { Total } \\
\mathrm{g} / \mathrm{kg})\end{array}$ & $\begin{array}{c}\text { Total } \\
(\mathrm{g} / \mathrm{kg})\end{array}$ \\
$\begin{array}{c}\mathrm{Zn} / \mathrm{kg}) \\
(\mathrm{g})\end{array}$ \\
\hline $1^{\text {st }}$ & 42.24 & 6.96 & 1.42 & 18.82 & 1.49 & 12.63 & 0.32 & 1.24 & 2641 & 708 & 104 \\
\hline $2^{\text {nd }}$ & 32.02 & 7.14 & 2.21 & 32.68 & 1.95 & 16.76 & 0.58 & 0.94 & 2087 & 801 & 188 \\
\hline
\end{tabular}


Table 1d: Some chemical properties of the irrigation water.

\begin{tabular}{|c|c|c|c|c|c|c|c|c|c|c|c|}
\hline Season & PH & \multirow{2}{*}{$\begin{array}{c}\text { EC } \\
\end{array}$} & & SAR & \multicolumn{3}{|c|}{ Soluble Cations (meq/l) } & \multicolumn{4}{|c|}{ Soluble Anions (meq/l) } \\
\cline { 5 - 12 } & & & $\mathrm{Ca}^{++}$ & $\mathrm{Mg}^{++}$ & $\mathrm{Na}^{+}$ & $\mathrm{K}^{+}$ & $\mathrm{CO}_{3}{ }^{-}$ & $\mathrm{HCO}_{3}{ }^{-}$ & $\mathrm{Cl}^{-}$ & $\mathrm{SO}_{4}{ }^{=}$ \\
\hline \hline $1^{\text {st }}$ & 7.13 & 2.54 & 5.04 & 5.03 & 7.02 & 12.85 & 0.52 & - & 4.43 & 14.23 & 6.76 \\
\hline $2^{\text {nd }}$ & 7.08 & 3.26 & 6.64 & 6.06 & 8.12 & 18.05 & 0.4 & - & 6.47 & 17.14 & 9.02 \\
\hline
\end{tabular}

The experiment carried out in a split plot design with four replicates at random procedure. Irrigation system treatments were used as the main plots (120 m length) namely: every long-furrow irrigation (EFI), and alternate long-furrow irrigation (AFI). Three different water inflow rates designated as $\mathrm{Q}_{1} ; \mathrm{Q}_{2}$; and $\mathrm{Q}_{3}$ represented the sub plots: 105, 90, and 65 $\mathrm{lpm} /$ furrow, respectively. (EFI) means that every furrow in the treatment irrigated during each watering, and (AFI) means that one of the two neighboring furrows was alternately irrigated during consecutive watering. Farmyard manure compost applied during land preparation at the rate of 12 ton/fed.-season, all recommended agricultural practices (i. e. land preparation, fertilization, weed control.. etc) were done.

Faba bean (Vicia faba, L.) varity Giza 717 was sown on 24 October, 2004. Sunflower (Helianthus annus, sp.) variety Sakha 53 was sown on 15 May 2005. Average plant densities were 6 and 4.5 plants $/ \mathrm{m}^{2}$ for sunflower and faba bean, respectively.

\section{- Irrigation systems and water management:}

Two irrigation systems and three irrigation water inflow rates were considered in this study. Water was applied through PVC spill pipes 80.0 $\mathrm{cm}$ length (75 and $63 \mathrm{~mm}$ diameter) installed in irrigation channel against the upper end of the furrows, which convey the water according to the required flow rate (one spill pipe for each furrow). The temporary dam was used to keep a constant hydraulic head, to realize adequately inflow rate during irrigation events. The inflow rates were 105, 90, and 65 lpm/furrow, which predetermined according to the technique of Merriam et al. (1983). The amount of water applied was estimated by a flow meter installed on the delivery line of the irrigation system. Soil surface slope was $0.25 \%$. Irrigation cutoff was at $90 \%$ of furrow length and runoff was negligible, which the furrows were closed-ends. The amounts applied during each irrigation event was appropriate to the crop's growth stage 
for both irrigated crops according to the methodology as described by Dorrenbos and Pruitt (1977), soil water content was measured by gravimetric method (Merriam et al.1983) before and after irrigation events in both wet and dry furrow under AFI system and other treatments along furrow length to a depth of $1.0 \mathrm{~m}$ in depth increments of $0.2 \mathrm{~m}$ to evaluate the soil moisture distribution and irrigation performance. The amount of rainfall was $112 \mathrm{~mm}$ along the winter season. The amount of irrigation water calculated according to the equation given by James (1988):

$$
E T_{c}=I+P \pm \Delta S-R-D
$$

Where: $E T_{c} \quad=$ crop evapotranspiration $(\mathrm{mm})$;

$I \quad=$ irrigation amount $(\mathrm{mm})$;

$P \quad=$ precipitation $(\mathrm{mm})$

$\Delta S \quad=$ change of soil water storage $(\mathrm{mm}) ;$

$R \quad=$ surface runoff (mm); and

$D \quad=$ deep percolation below crop root zone $(\mathrm{mm})$.

\section{- Applied irrigation water (Q):}

The volume of water applied for each plot was calculated by the following relationship:

Where:

$$
Q=q \times T \times n
$$

$\mathrm{Q}=$ water volume, $1 /$ plot,

$\mathrm{q}=$ irrigation water inflow rate per furrow, $1 / \mathrm{min}$.,

$\mathrm{T}=$ total irrigation time per furrow, min., and

$\mathrm{n}=$ number of furrows per plot.

The irrigation water inflow rate per furrow (q) was calculated by the following relationship (Merriam et al., 1983):

Where:

$$
q=0.0226 D^{2} \sqrt{h}
$$

$$
\begin{aligned}
& \mathrm{q}=\text { water inflow rate }(1 / \mathrm{sec} .) \\
& \mathrm{h}=\text { average effective head }(\mathrm{cm}), \text { and } \\
& \mathrm{D}=\text { inside diameter of the spill pipe }(\mathrm{cm}) .
\end{aligned}
$$




\section{-Application efficiency (AE\%) and water distribution uniformity (DU):}

Application efficiency (AE\%) was calculated for the $100 \mathrm{~cm}$ soil depth according to James (1988) as an average values of $2^{\text {nd }}, 4^{\text {th }}$ and $6^{\text {th }}$ irrigation events, also the distribution uniformity (DU), was calculated according to Clemmens and Solomon (1997). all data were statistically analyzed according to Snedecor and Cochran, (1973).

\section{- Yield assessment:}

Yield samples were taken in four locations along the furrow length (at $1^{\text {st }}$, $2^{\text {nd }}, 3^{\text {rd }}$ and $4^{\text {th }}$ quarter denoted as $1 / 4 \mathrm{~L}, 1 / 2 \mathrm{~L}, 3 / 4 \mathrm{~L}$ and $4 / 4 \mathrm{~L}$, respectively) with four replications, each replicate was one square meter harvested handely. Seeds were dried and adjusted to $15.5 \%$ water content. All data were statistically analyzed according to Snedecor and Cochran, (1973).

\section{- Oil content percent (OC \%) in sunflower seeds (total lipids):}

The crude oil content in samples was determined according to the procedure described by A.O.A.C (1995) by extracting with n-hexane (60$70^{\circ} \mathrm{C}$ ) using Soxhlet apparatus.

\section{- Irrigation water use efficiency (IWUE):}

It was measured according to James (1988) as follows:

$$
\text { IWUE }=\frac{Y}{W_{a}}
$$

Where:

$$
\begin{aligned}
& \text { IWUE }=\text { irrigation water use efficiency, } \mathrm{kg} / \mathrm{m}^{3} \\
& \mathrm{Y} \quad=\text { total dry seed yield, } \mathrm{kg} / \text { fed., and } \\
& \mathrm{W}_{\mathrm{a}} \quad=\text { total applied water, } \mathrm{m}^{3} / \mathrm{fed} .
\end{aligned}
$$

RESULTS AND DISCUSSIONS

\section{- Irrigation performance:}

Irrigation performance parameters calculated for the applied treatments are shown in Fig. $(1, A$ and $B)$, it is clear that under EFI from the values of application efficiency (AE\%) with faba bean, Fig. (1, A) showed that about 18.0, 16.7 and $21.4 \%$ of the water applied were not available for the crop with $\mathrm{Q}_{1}, \mathrm{Q}_{2}$ and $\mathrm{Q}_{3}$ water application treatments, respectively. 
In the second season, these losses with sunflower under EFI were 18.7, 16.6 and $18.9 \%$, respectively. While, with the AFI with faba, these losses were about 10.9, 10.9 and $14.1 \%$, respectively, and with sunflower, it were $8.7,9.6$ and $10.5 \%$, respectively. According to these results; with low inflow rates, the AE\% was less than that with high inflow rates, similar trend were reported by Azevedo et al. (2001).
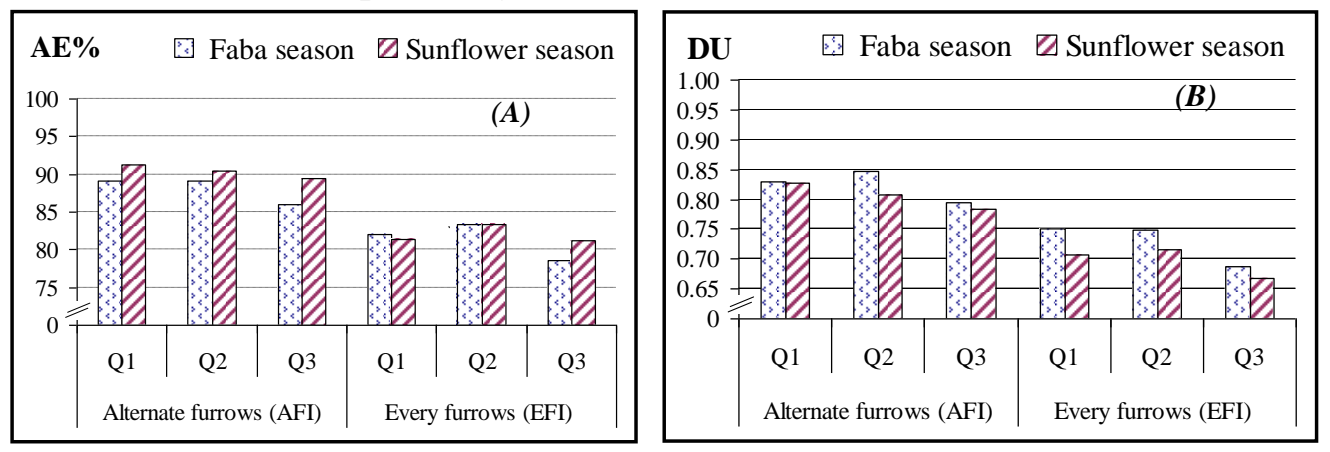

Fig. 1, A and B: Average values of water application efficiency (AE\%) and distribution uniformity (DU) for applied irrigation systems under considered inflow rates with faba and sunflower seasons.

The average values of water distribution uniformity (DU) for treatments under considered irrigations are shown in Fig. $(1, \mathrm{~B})$ the highest average value of DU obtained 0.83 in faba season by $A F I$ with $Q_{1}$, it was representing an increase by $12.8 \%$ compared to EFI at the same inflow rate $\mathrm{Q}_{1}$. The increment values reached to 13.1 and $23.3 \%$ compared with $\mathrm{Q}_{2}$ and $\mathrm{Q}_{3}$, respectively by AFI. While in the sunflower season, the highest average value was 0.83 at AFI and $\mathrm{Q}_{1}$ treatment, it representing an increase by $8.99 \%$ compared to EFI at the same inflow rate. The increment values reached to 2.64 and $5.74 \%$ compared with $\mathrm{Q}_{2}$ and $\mathrm{Q}_{3}$, respectively by AFI. Significant increases of DU with AFI were obtained comparing to EFI under the experiment conditions. These results interpreted regarding to the water inflow rate, has to be determined for each field situation according to slope, advance phase, intake opportunity time, furrow length and depth of application, Mintesinot et al. (2004).

By considering to the effect of the water infiltration profile on the blocked furrow irrigation performance under field conditions, the irrigation management with alternately blocked furrows, besides to avoid the runoff 
losses, improves the water distribution uniformity, contributing for a better furrow irrigation performance. The variations on water advance time along the furrow irrigation are mostly responsible for variations on infiltration opportunity time, which result on non-uniform water infiltration profile, Pordeus et al. (2003). Alternately blocked furrows allow the infiltration rate was lower, the infiltrated water depths at the end of the field were larger than at the beginning of the field, allowing a more adequate management strategy with a smaller water application time; consequently, the water uniformity distribution in blocked furrows with alternately increased, Kang et al. (2000 a) and Lima et al. (2003).

Average soil moisture changes in $60 \mathrm{~cm}$ soil depth for AFI and EFI in faba growing season are presented in Fig. (2), and with sunflower growing season are presented in Fig. (3).
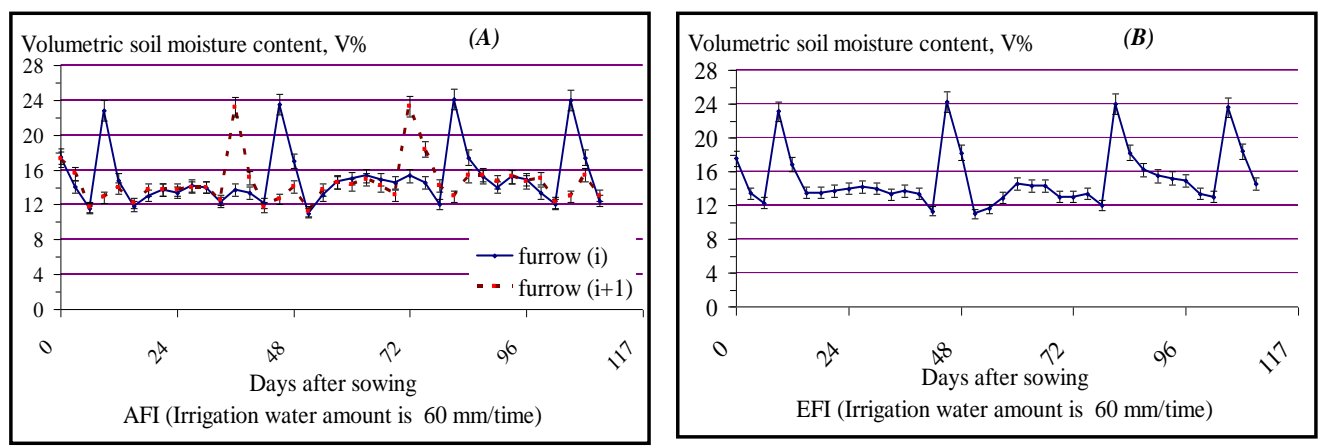

Fig. 2: Average soil moisture content (v\%) in the top $60 \mathrm{~cm}$ layer during faba season by AFI (A) and EFI (B) treatments.
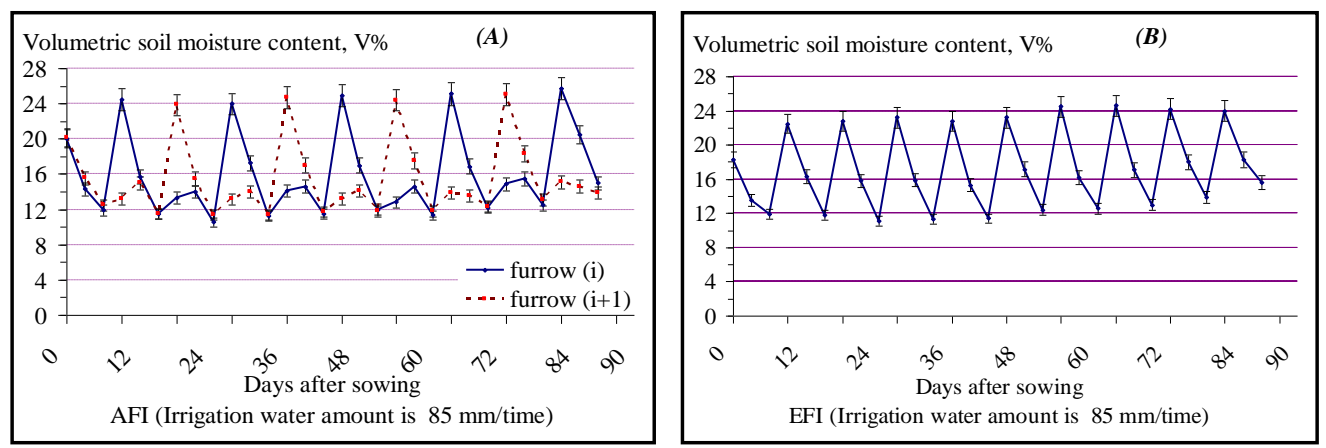

Fig. 3: Average soil moisture content (v\%) in the top $60 \mathrm{~cm}$ layer during sunflower season by AFI (A) and EFI (B) treatments. 
It were shown that the soil moisture contents between the two neighboring furrows in AFI remained different until the next irrigation, with a higher water content in the previously irrigated furrow. This pattern of soil moisture distribution in the crop root zone should allow part of the root system to be always exposed to a drying soil, consequently, the uniformity of soil moisture distribution in the AFI treatments didn't change noticeably when irrigation amounts was reduced, Kang et al. (2000 a).

\section{- Effect of treatments on faba seed yield:}

The effect of water quantity and irrigation system treatments on the seed yield of faba crop is shown in Fig. (4).

Regarding the interactions among the considered treatments, yield data showed different trends that varied due to the irrigation system; there were significant differences between AFI and EFI treatments.

AFI system increased by 12.2, 11,0 and $6.7 \%$ in the average faba seed yield as compared to EFI system under water application $\mathrm{Q}_{1}, \mathrm{Q}_{2}$ and $\mathrm{Q}_{3}$, respectively. While the respective significant increments compared to treatment $\mathrm{Q}_{1}$ with AFI amounted 12.2, 14.4 and $16.4 \%$ of seed yield due to $\mathrm{Q}_{1}, \mathrm{Q}_{2}$ and $\mathrm{Q}_{3}$ treatments with EFI system, respectively.

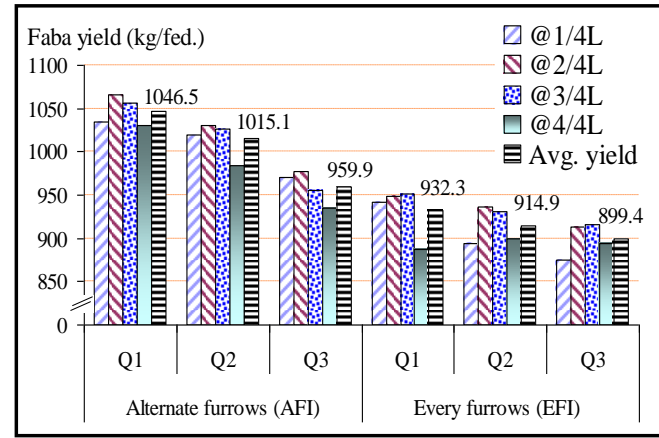

Fig. 4: Effect of treatments on faba yield along the field length.

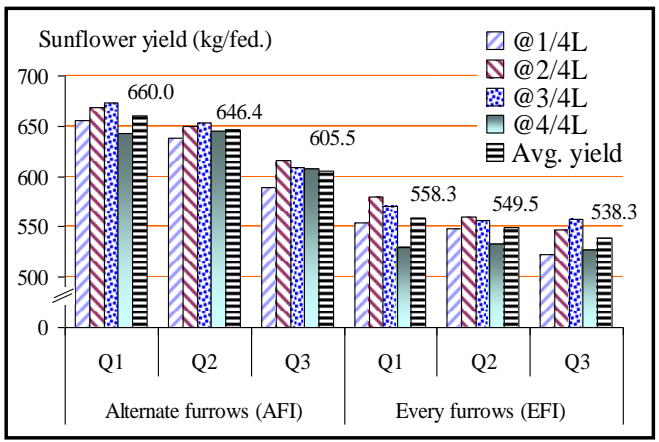

Fig. 5: Effect of treatments on sunflower yield along the field length

These increases in seed yield were significant with $2 / 4 \mathrm{~L}$ and $3 / 4 \mathrm{~L}$ of furrow length compared with $1 / 4 \mathrm{~L}$ and $4 / 4 \mathrm{~L}$ under both AFI and EFI systems. The main reasons may be alternate furrow irrigation has caused good aeration of roots in soil; and enhanced structure of the soil and soil 
moisture content, (Chambal and Shukla, 2006). While lower yield with EFI system was attributed to irrigation water ponds at the furrow ends after irrigation event, which too much water might have caused partially poor aeration of roots, and soil nutrients leaching, (Xiao et al., 2004).

\section{- Effect of treatments on sunflower seed yield:}

The effect of water quantity and irrigation system on the seed yield of sunflower crop is shown in Fig. (5). AFI system increased in the average sunflower seeds yield by 18.2, 17.6 and $12.5 \%$ as compared to EFI system under water application $\mathrm{Q}_{1}, \mathrm{Q}_{2}$ and $\mathrm{Q}_{3}$, respectively. These increases in seed yield were significant with $2 / 4 \mathrm{~L}$ and $3 / 4 \mathrm{~L}$ of furrow length compared to $1 / 4 \mathrm{~L}$ and $4 / 4 \mathrm{~L}$ under both AFI and EFI systems. This may be rendered to prolonged moisture stress as a result of long intervals between irrigation (El-Kommos and Nour El-Din, 1990). Also, long irrigation intervals cause increase in respiration (loss of water) and detriment of photosynthesis upon increasing water stress (Ghazy et al., 1987). Drought and high salinity are two of the most important environmental stresses that alter plant water status and severely limit plant growth and development, and thus crop productivity. (Liu and Baird, 2003). However, these results are accordance with that obtained by Beheiry and Hiekal (2007) who observed similar findings, that AFI system increased sunflower seeds yield by $14.0 \%$ as compared to EFI regardless of water quantity treatments.

\section{Effect of treatments on sunflower seeds oil content percent $(\mathrm{O} \mathrm{C} \%$ ):}

Data in Table (2) indicate that the oil content percent (OC\%) in seeds was significantly increased due to irrigation system and water quantity, while, the increase of oil content percent was proportional to the length of the field which amounted to $2.2,7.9$ and $6.5 \%$ over the last quarter $(4 / 4 \mathrm{~L})$ of the mean values of $1 / 4 \mathrm{~L}, 2 / 4 \mathrm{~L}$, and $3 / 4 \mathrm{~L}$, respectively, regardless of irrigation system and water quantity treatments. On the other hand, OC\% in seeds was significantly increased due to water quantity regardless irrigation system and length of the field treatments. The increase of oil content was 3.7 and $4.5 \%$ over $\mathrm{Q}_{3}$ treatment for the mean values of $\mathrm{Q}_{1}$ and $\mathrm{Q}_{2}$ treatments, respectively. 
Also, it is obvious that the oil content in seeds was relatively higher under AFI and $\mathrm{Q}_{2}$ compared to EFI treatments. That maybe attributed to salinity affects on growth, development and some seed characteristics, mainly oil content and also influence nutrient uptake according to Weiss (2000).

Table (2): Effect of treatments on oil content (\%) of sunflower seeds

\begin{tabular}{|c|c|c|c|}
\hline Irrig. system (I ) & Water q. (Q) & Field length (L) & Oil Cont. (\%) \\
\hline \multirow{14}{*}{ AFI } & \multirow{3}{*}{$\mathrm{Q}_{1}$} & $\frac{1 / 4 \mathrm{~L}}{2 / 4 \mathrm{~L}}$ & $\begin{array}{l}45.30 \\
46.17\end{array}$ \\
\hline & & $3 / 4 \mathrm{~L}$ & 44.90 \\
\hline & & $4 / 4 \mathrm{~L}$ & 42.01 \\
\hline & \multicolumn{2}{|l|}{ Mean of $\mathrm{Q}_{1}$} & 44.60 \\
\hline & \multirow{4}{*}{$\mathrm{Q}_{2}$} & $1 / 4 \mathrm{~L}$ & 45.23 \\
\hline & & $2 / 4 \mathrm{~L}$ & 46.67 \\
\hline & & $3 / 4 \mathrm{~L}$ & 46.36 \\
\hline & & $4 / 4 \mathrm{~L}$ & 43.93 \\
\hline & \multicolumn{2}{|l|}{ Mean of $\mathrm{Q}_{2}$} & 45.55 \\
\hline & \multirow{4}{*}{$\mathrm{Q}_{3}$} & $1 / 4 \mathrm{~L}$ & 38.85 \\
\hline & & $2 / 4 \mathrm{~L}$ & 45.95 \\
\hline & & $3 / 4 \mathrm{~L}$ & 45.63 \\
\hline & & $4 / 4 \mathrm{~L}$ & 41.26 \\
\hline & \multicolumn{2}{|l|}{ Mean of $\mathrm{Q}_{3}$} & 42.92 \\
\hline \multicolumn{3}{|l|}{ Mean of AFI } & 44.36 \\
\hline \multirow{15}{*}{ EFI } & \multirow{4}{*}{$\mathrm{Q}_{1}$} & $1 / 4 \mathrm{~L}$ & 43.01 \\
\hline & & $2 / 4 \mathrm{~L}$ & 43.43 \\
\hline & & $3 / 4 \mathrm{~L}$ & 42.04 \\
\hline & & $4 / 4 \mathrm{~L}$ & 40.75 \\
\hline & \multicolumn{2}{|l|}{ Mean of $Q_{1}$} & 42.31 \\
\hline & \multirow{4}{*}{$\mathrm{Q}_{2}$} & $1 / 4 \mathrm{~L}$ & 40.71 \\
\hline & & $2 / 4 \mathrm{~L}$ & 42.13 \\
\hline & & $3 / 4 \mathrm{~L}$ & 44.00 \\
\hline & & $4 / 4 \mathrm{~L}$ & 41.43 \\
\hline & \multicolumn{2}{|l|}{ Mean of $\mathrm{Q}_{2}$} & 42.07 \\
\hline & \multirow{4}{*}{$10 x \cos 2$} & $1 / 4 \mathrm{~L}$ & 40.40 \\
\hline & & $2 / 4 \mathrm{~L}$ & 43.24 \\
\hline & & $3 / 4 \mathrm{~L}$ & 41.27 \\
\hline & \multirow{2}{*}{\multicolumn{2}{|c|}{ Mean of $Q_{3}$}} & 38.67 \\
\hline & & & 40.90 \\
\hline \multicolumn{3}{|l|}{ Mean of EFI } & 41.76 \\
\hline \multicolumn{3}{|l|}{ Grand mean } & 43.06 \\
\hline \multicolumn{4}{|c|}{ L.S.D $(<0.05)$} \\
\hline \multicolumn{3}{|l|}{$\mathrm{L}$} & 0.27 \\
\hline \multicolumn{3}{|l|}{ L\&I } & 0.38 \\
\hline \multicolumn{3}{|l|}{$\mathrm{L} \& \mathrm{Q}$} & 0.46 \\
\hline \multirow{2}{*}{\multicolumn{3}{|c|}{$\mathrm{Q}$}} & 0.46 \\
\hline & & & 0.14 \\
\hline \multicolumn{3}{|l|}{ I\&Q } & 0.20 \\
\hline \multicolumn{3}{|l|}{ L\&I\&Q } & 0.65 \\
\hline
\end{tabular}




\section{Irrigation water use efficiency (IWUE):}

The average values of IWUE are shown in Fig. (6) by faba crop with considered water amounts under irrigation systems, the values of AFI were higher than that in all of EFI. Thus, in the case of AFI, the highest average value was $0.83 \mathrm{~kg} / \mathrm{m}^{3}$ obtained under $\mathrm{Q}_{3}$, while, under $\mathrm{Q}_{2}$ and $\mathrm{Q}_{1}$, the declines reached to 21.38 and $43.45 \%$, respectively. While, the increments reached to $6.73,34.67$ and $61.02 \%$ over the EFI under the treatments $\mathrm{Q}_{3}, \mathrm{Q}_{2}$, and $\mathrm{Q}_{1}$, respectively.
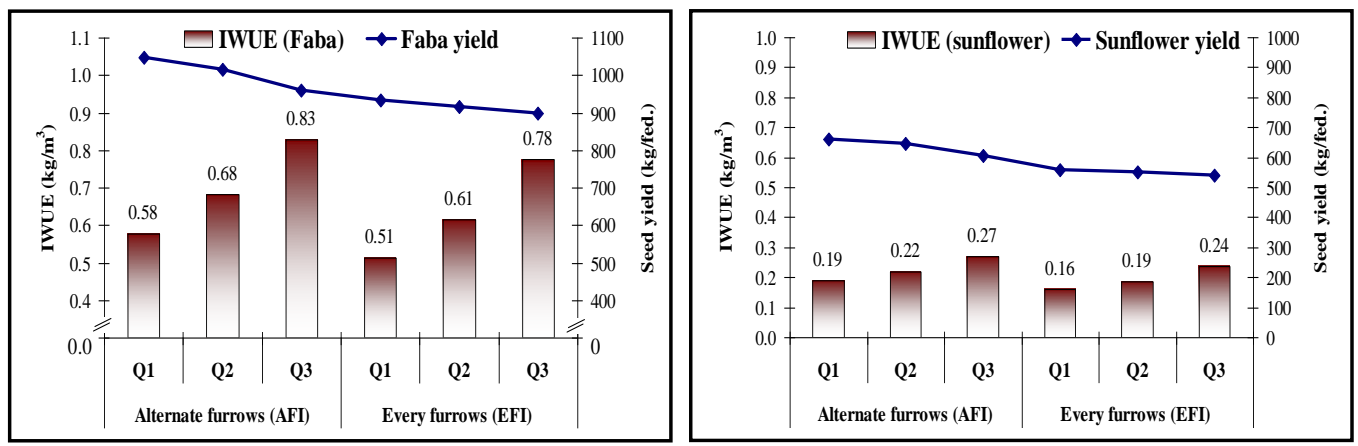

The average values of IWUE calculated for sunflower crop with considered

Fig. 6: Average IWUE obtained by faba crop with water amounts under irrigation systems.
Fig. 7: Average IWUE obtained by sunflower crop with water amounts under irrigation systems.

water amounts under irrigation systems are shown in Fig. (7), the values of AFI were higher than that in all of EFI. Thus, in the case of AFI, the highest average value was $0.27 \mathrm{~kg} / \mathrm{m}^{3}$ obtained under $\mathrm{Q}_{3}$, while, under $\mathrm{Q}_{2}$ and $\mathrm{Q}_{1}$, the declines reached to 22.23 and $32.52 \%$, respectively.

While, the increments reached to $12.48,44.63$ and $66.68 \%$ over the EFI under the treatments $\mathrm{Q}_{3}, \mathrm{Q}_{2}$, and $\mathrm{Q}_{1}$, respectively. This is could be attributed to the reduction in the amount of water applied and maintaining the entire irrigation period caused a significantly decrease in yield, (Plaut and Grava, 1999) who observed similar findings, that a sharp decline in yield was found under limiting irrigation water, and attributed to decreases of the number of seeds per head and average seeds weight.

\section{- Irrigation water consumed:}


Under the two irrigation systems, irrigation water amounts with faba season were $1814.7,1489.4$ and $1160.4 \mathrm{~m}^{3} /$ fed. applied by treatments $\mathrm{Q}_{1}$, $\mathrm{Q}_{2}$ and $\mathrm{Q}_{3}$, respectively. While with sunflower season, it was 3464.3, 2958.7 and $2254.2 \mathrm{~m}^{3} / \mathrm{fed}$., respectively, under the experiment conditions.

\section{CONCLUSION}

AFI is a practicable method, and should be of significant value to arid areas because many of these areas face diminishing water resources. A sustainable use of water resources is increasingly becoming an urgent world-wide problem. Moreover, the difference in yield is sufficient to do the extra work involved in changing the water management to alternate the flow to different furrows each irrigation event. The most important result from the two season investigation was that when less irrigation was introduced, the AFI had the least seed yield reduction. Such yield reductions were substantial and significant with EFI treatments. Both seasons' data showed that if the AFI method was used, less irrigation water could maintain the same seed yield production as that of conventional irrigation with high irrigation amounts. The deep percolation found in EFI was larger than in AFI. Therefore, more irrigated water was taken up by the plants with AFI than with EFI. This also contributed to the improvements of IWUE in the AFI treatments with better utilized of nutrients and DU of irrigation water in the soil. As well as, AFI increased OC\% in sunflower seeds by $6.2 \%$ over the EFI regardless of water quantity and the length of the field.

\section{REFERENCES}

A.O.A.C. (1995). Official methods of analysis of the association of official analytical chemists. $15^{\text {th. }}$ Ed. Published by the Association of Official Analytical Chemists Inc. suite 400, 200 Wilson Baulevard-Arligton Virgina 22201, USA. pp. 69-90.

Azevedo, C. A. V. de; R. V.Pordeus; V. L. A. de Lima and J. D. Neto (2001). Behavior of the optimal discharge in furrow irrigation with continuous flow. ASAE Annl. Int. Mtg, Sacramento, California, USA, July-29 to Aug.-1, 2001, ASAE Paper No. 012165. 
Beheiry, G. Gh. S. and H. A. M. Hiekal (2007). Evaluation of the relationship between natural amendments application and different irrigation systems on calcareous soil properties and its productivity. Egypt. J. Appl. Sc., 22(6A): 310-329, Egypt.

Benham, B. L., D. E. Eisenhauer, C. D. Yonts and D.Varner (1997). Managing furrow irrigation systems. Cooperative Ex. G97-1338 Irrigation Operations and Management, Nebraska U. -Lincoln, USA.

Black, C. A. (1983). Methods of soil analysis. Part 2, Agron. Monogr. No.9, ASA, Madison, WI, USA.

Chambal, P. and S. Shukla (2006). Effects of Soil Organic amendment on Water and Nutrient Movement in a Sandy Soil. ASABE Annl. Int. Mtg., Oregon Convention Center Portland, Oregon 9 - 12 July. ASABE Paper No. 062007, 14pp., USA.

Clemmens A. J., Z. El-Haddad, and T. S. Strelkoff (1999). Assessing the potential for modern surface irrigation in Egypt. Trans. of the ASAE 42 (4): 995-1008.

Clemmens, A. J. and K. H. Solomon (1997). Estimation of global irrigation distribution uniformity. J. of Irrig. and Drain. Div., ASCE, 123(6):454-461.

Dorrenbos, J. and W. O. Pruitt (1977). Crop water requirements. FAO Irrigation and Drainage Paper 24,156 pp. Rome.

El-Kommos, F. and Y. Nour El-Din (1990). The effect of irrigation frequency under varying soil amendments application on wheat and broad beans production in sandy soils. Egypt. J. Soil Sci., 30(3):403414.

Francois, L. E. (1996). Salinity effects on four sunflower hybrids. Agron. J., 88:215-219.

Ghazy, A.; A. M. Selim and M. Z. Salem (1987). Effect of irrigation regime on the yield of wheat and efficiency of water use. Egypt. J. Soil Sci., 27 (3):387-396.

Graterol, Y. E., D. E. Eizenhaure and R. W. Elmore (1993). Alternate furrow-irrigation for soybean production. Agric. Water Manag. 24:133-145. 
Hanson, B. R., T. L., Pritchard and H. Schulbach (1993). Estimating furrow infiltration. Agric. Water Manag. 24: 281-98.

Hodges, M. E., J. F. Stone, J. E. Garton and D. L. Weeks (1989). Variance of water advance in wide spaced furrow irrigation. Agric. Water Manag. 16:5-13.

James, L. G. (1988). Principles of farm irrigation system design. Jone Willey \& Sons (Ed.), New York, 543 pp.

Kang, S., P. Shi, Y. Pan, Z. Liang, X. Hu and J. Zhang (2000 a). Soil water distribution, uniformity and water-use efficiency under Alternate furrow irrigation in arid areas. Irrig. Sci. 19, 181-190.

Kang, S., Z. Liang, Y. Pan, P. Shi and J. Zhang (2000 b). Alternate furrow irrigation for maize production in an arid area. Water Manag. 45, 267274.

Klute, A. A. (Ed.) (1986). Methods of soil analysis. Part 1, $2^{\text {nd }}$ Ed. Agron. Monogr. No. 9, ASA and SSSA, Madison, WI, USA.

Lima, V. L. A. de, J. D. Neto and M. R. de Queiroz (2003). Filed evaluation of water infiltration profile in opened and blocked furrow irrigation with continuous flow. ASAE Paper No.: 032244, Annl. ASAE Int. Mtg. Presentation, July 27-30, Las Vegas, NV, USA.

Liu, X. and W.V. Baird (2003). Differential Expression of Genes Regulated in Response to Drought or Salinity Stress in Sunflower. Crop Sci., 43:678-687.

Merriam, J. L.; M. N. Shearer and C. M. Burt (1983). Evaluating irrigation systems and practices. Chapter 17: M. E. Jensen (Ed.): Design and operation of farm irrigation systems. ASAE Monograph No. 3, USA.

Mintesinot, B., H. Verplancke, E. Van Ranst, and H. Mitiku (2004). Examining traditional irrigation methods, irrigation scheduling and alternate furrows irrigation on vertisols in northern Ethiopia. Agric. Water Manag. 64, 17-27.

Oyonarte, N. A. and L. Mateos (2002). Accounting for soil variability in the evaluation of furrow irrigation. Trans. of the ASAE 46(1): 8594. 
Plaut, Z. and A. Grava (1999). Response of sunflowers to quantities of irrigation water, irrigation regimes and salinities in the water and soil. In Water use in crop production, M. B. Kirkham (Ed.) by Haworth Press, Inc., pp. 299-315.

Pordeus, R. V.; C. A. V. de Azevedo; V. L. A. de Lima; J. D. Neto and M. R. Q. A. Azevedo (2003.). Field evaluation of water infiltration profile in opened and closed furrow irrigation with continuous flow. ASAE Paper No. 032244, ASAE Annl. Int. Mtg., July 27-30, Las Vegas, USA.

Rice, R. C., D. J. Hunsaker, F. J. Adamsen and A. J. Clemmens (2001). Irrigation and nitrate movement evaluation in conventional and alternate-furrow irrigated cotton. Trans. of the ASAE 44(3): 555568.

Roy, R. N.; A. Finck; G. J. Blair and H. L. S. Tandon (2006). Plant nutrition for food security. A guide for integrated nutrient management. FAO Fertilizer and Plant Nutrition Bulletin, 16.

Snedecor, G. W. and W. G. Cochran (1973). In "Statistical Methods". 6th Ed. Iowa State Univ. Press, Ames, USA.

Walker, W. R. (1989). Guidelines for designing and evaluating surface irrigation systems. FAO Irrig. and Drain. Paper 45: 148 pp., Italy.

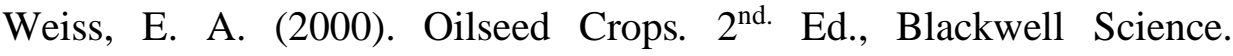
Australia, pp. 205-243.

Xiao, J.; T. W. Lei, P. F. Jiang and Y. D. Yu (2004). Effects of water quality in furrow irrigation on corn yield and soil salinity. Annl. ASAE/CSAE Mtg. Presentation Paper No. 042037, 1-4 August Ottawa, Canada. 


\section{الملخص العزبي

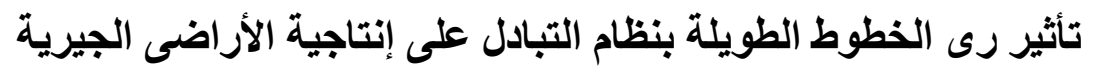

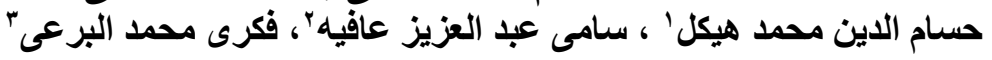

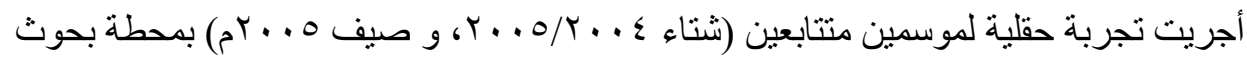

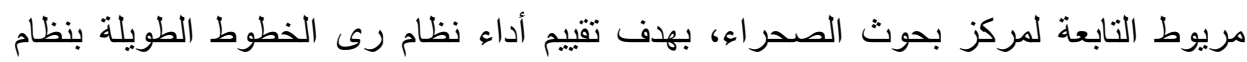

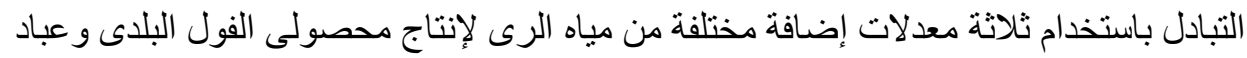

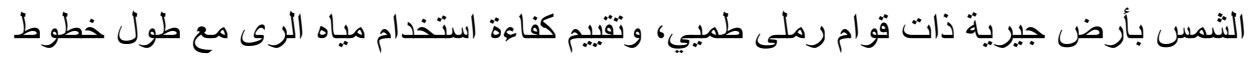

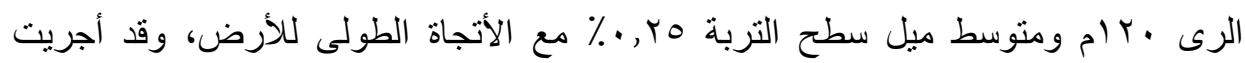

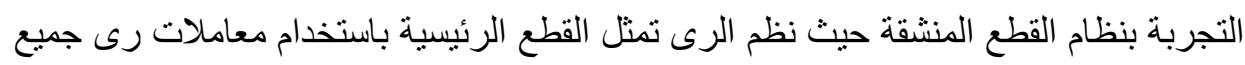

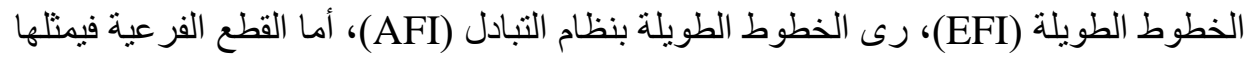

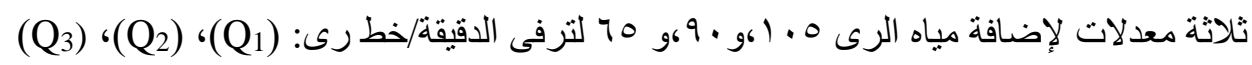

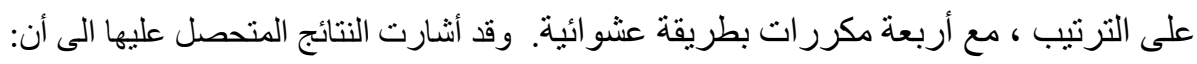

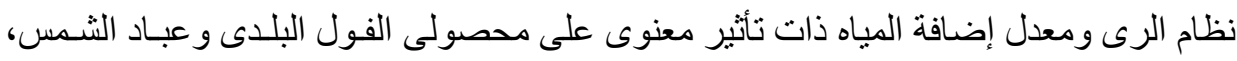

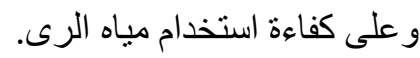

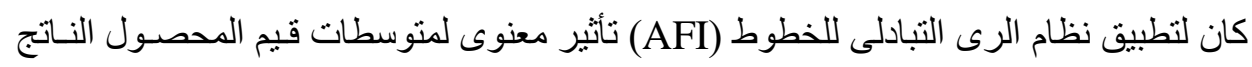

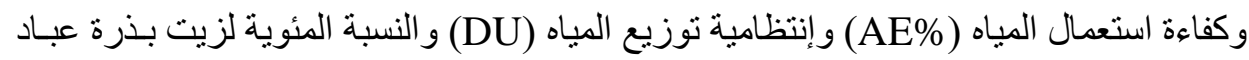

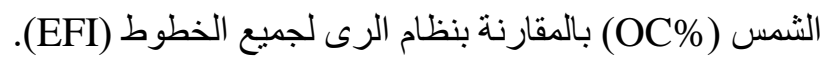

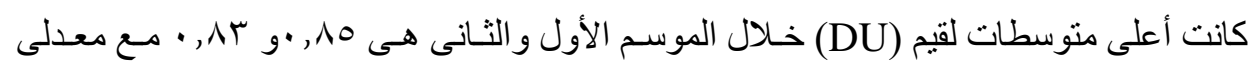

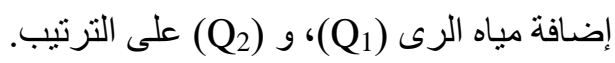

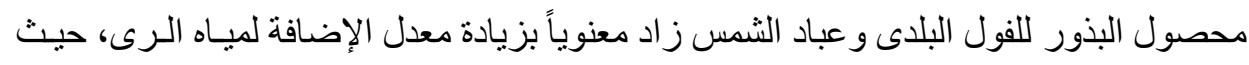

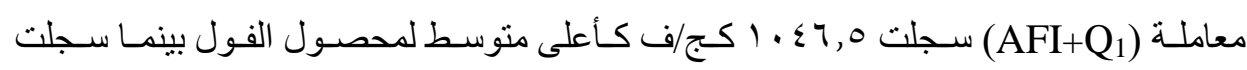
كان 90

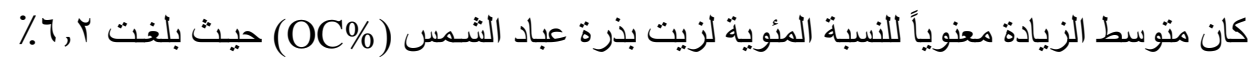
فى نظام الرى (AFI) مقارنة بنظام (EFI).

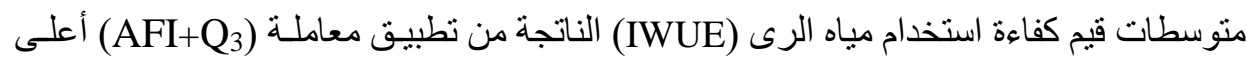

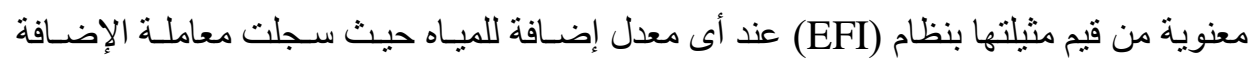
(AFI+Q3) الثمس تحت ظروف الدر اسة على الترتيب.

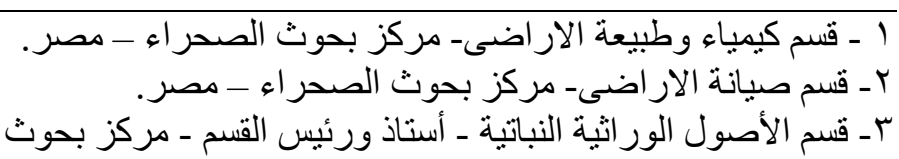

